2016

\title{
Bone Tools from Caddo Sites in the Angelina River Basin in East Texas
}

Timothy K. Perttula

Heritage Research Center, Stephen F. Austin State University

Mark Walters

Heritage Research Center, Stephen F. Austin State University

Follow this and additional works at: https://scholarworks.sfasu.edu/ita

Part of the American Material Culture Commons, Archaeological Anthropology Commons, Environmental Studies Commons, Other American Studies Commons, Other Arts and Humanities Commons, Other History of Art, Architecture, and Archaeology Commons, and the United States History Commons

Tell us how this article helped you.

This Article is brought to you for free and open access by the Center for Regional Heritage Research at SFA ScholarWorks. It has been accepted for inclusion in Index of Texas Archaeology: Open Access Gray Literature from the Lone Star State by an authorized editor of SFA ScholarWorks. For more information, please contact cdsscholarworks@sfasu.edu. 


\section{Bone Tools from Caddo Sites in the Angelina River Basin in East Texas}

Creative Commons License

(c) (i) (8)

This work is licensed under a Creative Commons Attribution-NonCommercial 4.0 International License 


\title{
Bone Tools from Caddo Sites in the Angelina River Basin in East Texas
}

\author{
Timothy K. Perttula and Mark Walters
}

\section{INTRODUCTION}

In addition to the use of stone for tools, ancestral Caddo communities in East Texas also relied on organic materials for tools, including animal bones and plant parts (i.e., cane and wood). Bone tools were an important part of the technological system of Caddo groups and their study helps to understand the range of activities that occurred at Caddo sites in particular locations and regions. However, they are often not preserved in habitation deposits and features on East Texas Caddo sites due to bioturbation and erosion of sandy sediments where artifacts came to accumulate during an occupation or series of occupations. Several ancestral Caddo sites in the Lake Sam Rayburn area in the Angelina River basin do have well-preserved animal bone tools, and we consider their function and use in the remainder of this article.

\section{Bone Tools from Lake Sam Rayburn Caddo Sites}

Five different Caddo sites at Lake Sam Rayburn have bone tools. Of the 43 bone tools and tool fragments, more than 76 percent are from the Late Caddo (i.e., Late Angelina phase) archaeological deposits at the Walter Bell site. The other Late Caddo phase site at Lake Sam Rayburn with bone tools is the Etoile (41NA11, $\mathrm{n}=2$ ); there is also a turtle shell rattle from the Walter Bell site. The remainder of the bone tools $(\mathrm{n}=8,18.6$ percent) are from apparent Early Angelina phase components at the Sawmill (41SA89), Blount (41SA123), and Print Bell (41SB36) sites.

\section{Etoile Site (41NA11)}

There are two bone tools in the assemblage at the Etoile site. The first is a $6.5 \mathrm{~cm}$ long antler flaking tool with a cut and smoothed edge opposite the working tip; the antler is a maximum of $1.5 \mathrm{~cm}$ in thickness. The other tool is a deer ulna awl fragment $(6.1 \mathrm{~cm}$ in length and $2.7 \mathrm{~cm}$ in width) with a smoothed and worked tip.

\section{Sawmill Site (41SA89)}

There are five bone tools in the Sawmill site artifact assemblage. Three are antler tine flaker fragments, two of which have been burned, an antler beam with biconically drilled holes or sockets, and a deer bone ulna awl (Figure 1a-b). The drilled antler beam is part of an unfinished handle to an unidentified tool form. It is $67.7 \mathrm{~mm}$ in length and $11.6 \mathrm{~mm}$ in width, and the drilled holes or sockets are $4.2 \mathrm{~mm}$ in diameter. The tip of the ulna awl has been extensively worked and rounded from use; it is $102.0 \mathrm{~mm}$ in length and a maximum of $38.1 \mathrm{~mm}$ in width (Figure $1 \mathrm{~b}$ ).

\section{Blount Site (41SA123)}

A deer ulna awl fragment is the only bone tool in the Blount site assemblage. The fragment is broken at the working edge, and the remaining piece is $100.5 \mathrm{~mm}$ in length and $39.2 \mathrm{~mm}$ in maximum width (Figure 2). 


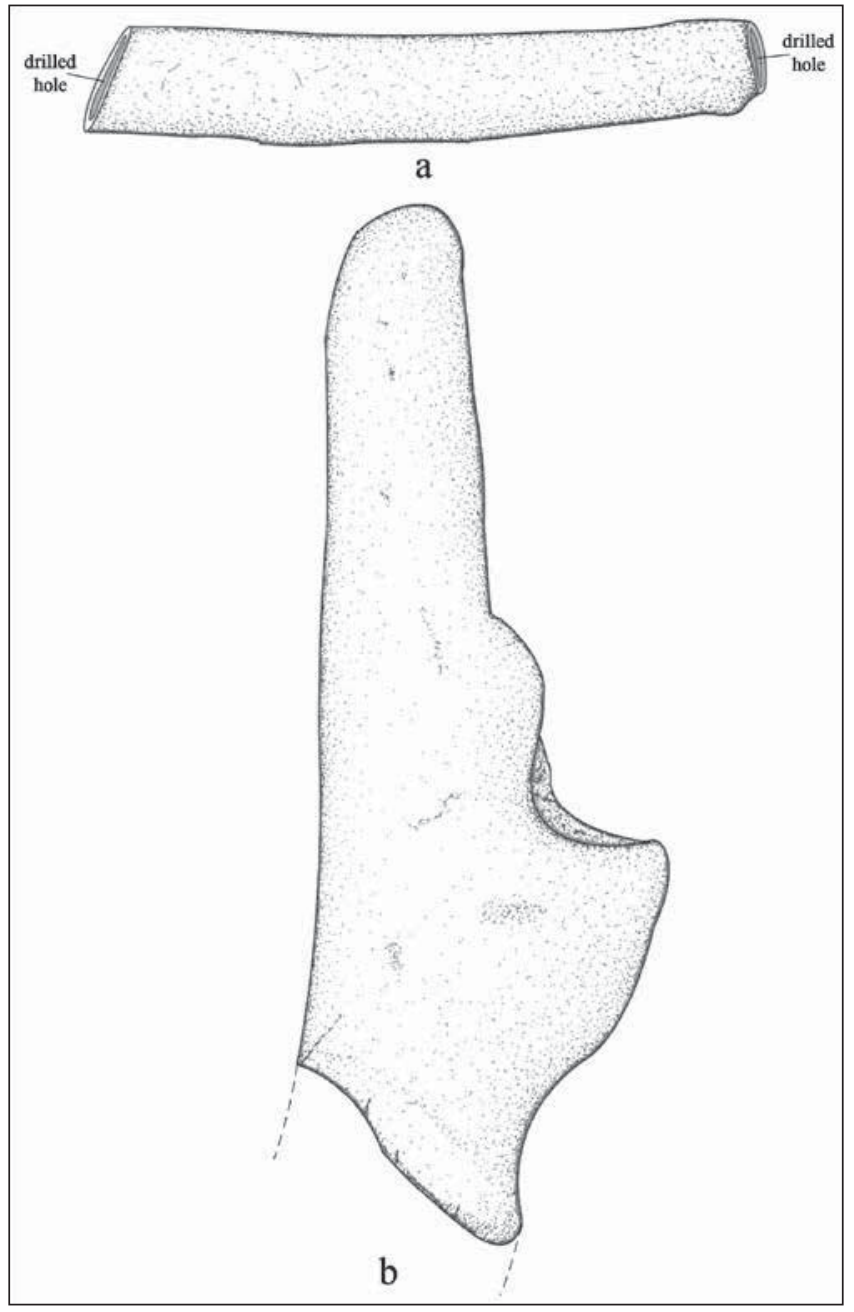

Figure 1. Selected bone tools from the Sawmill site.

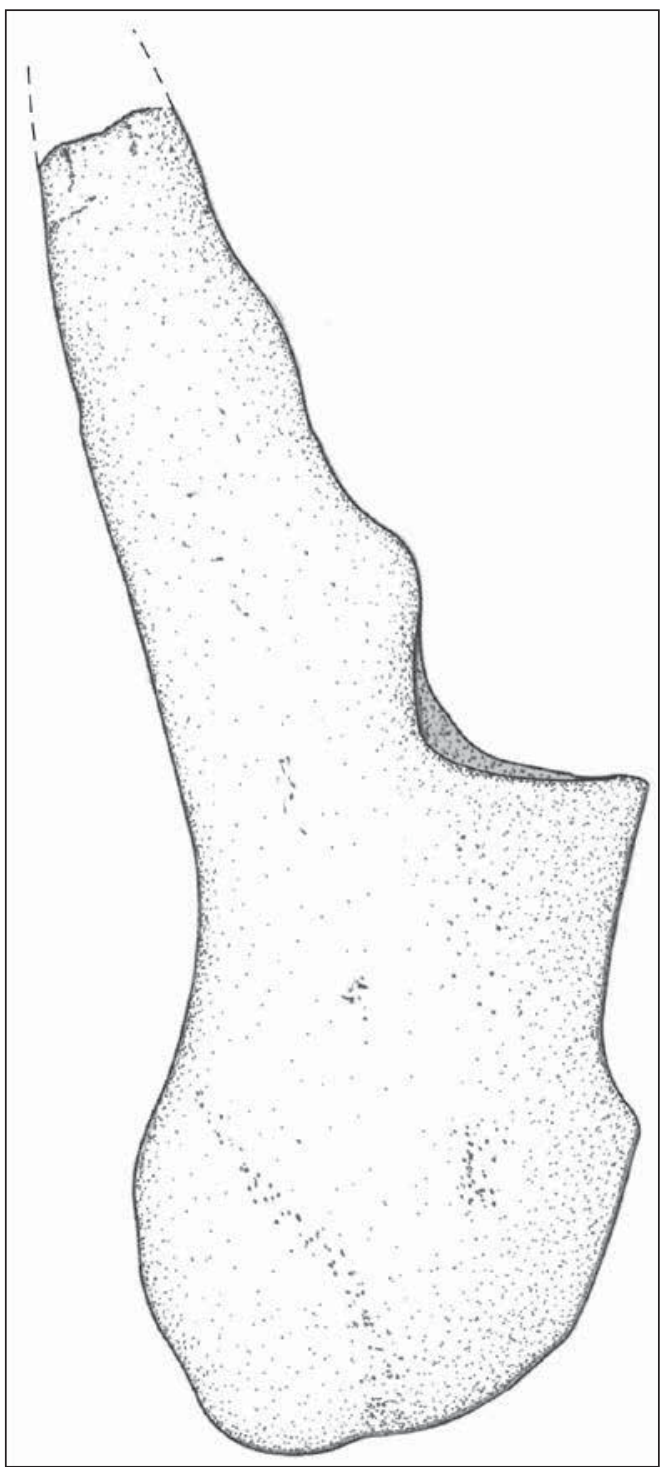

Figure 2. Deer ulna awl fragment from the Blount site. 


\section{Print Bell Site (41SB36)}

In addition to a deer ulna tool fragment, there is a fragment of an antler tine tool at the Print Bell site. The tine fragment has been polished and is $>40 \mathrm{~mm}$ in length and $8.9 \mathrm{~mm}$ in width.

Walter Bell Site (41SB50)

The Walter Bell site has a large assemblage of bone tools $(n=33)$. This includes one fish hook with a notched head (Figure 3). The fish hook is 28.2 $\mathrm{mm}$ in length and $3.3 \mathrm{~mm}$ in maximum width, but only $2.0 \mathrm{~mm}$ thick near the end of the hook.

The most common bone tools are deer ulna awls $(\mathrm{n}=13)$ with smoothed working tips (Figure $4 \mathrm{a}-\mathrm{c}$ ). The complete awls range from 113-114.0 mm in length and 35.5-36.9 $\mathrm{mm}$ in width. There are also a number of antler tine flaking tools and fragments thereof $(\mathrm{n}=9)$ with polished working tips (Figure $5 \mathrm{a}-\mathrm{b})$. The larger antler tine tools range from $82.3-127.0+\mathrm{mm}$ in length and $12.1-20.1 \mathrm{~mm}$ in width. Most of the antler tool fragments (78 percent) have been burned.

In addition to the antler tine tools, there are also two worked deer antler shafts. These are cut pieces with drilled cavities or sockets at either end of the cut shaft (cf. Girard et al. 2011:Figure 25). These tools are likely unfinished handles that range from $61-68.3 \mathrm{~mm}$ in length and $16.5-29.0 \mathrm{~mm}$ in width.

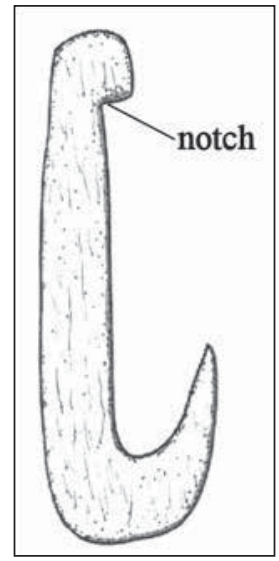

Figure 3. Bone fish hook from the Walter Bell site.

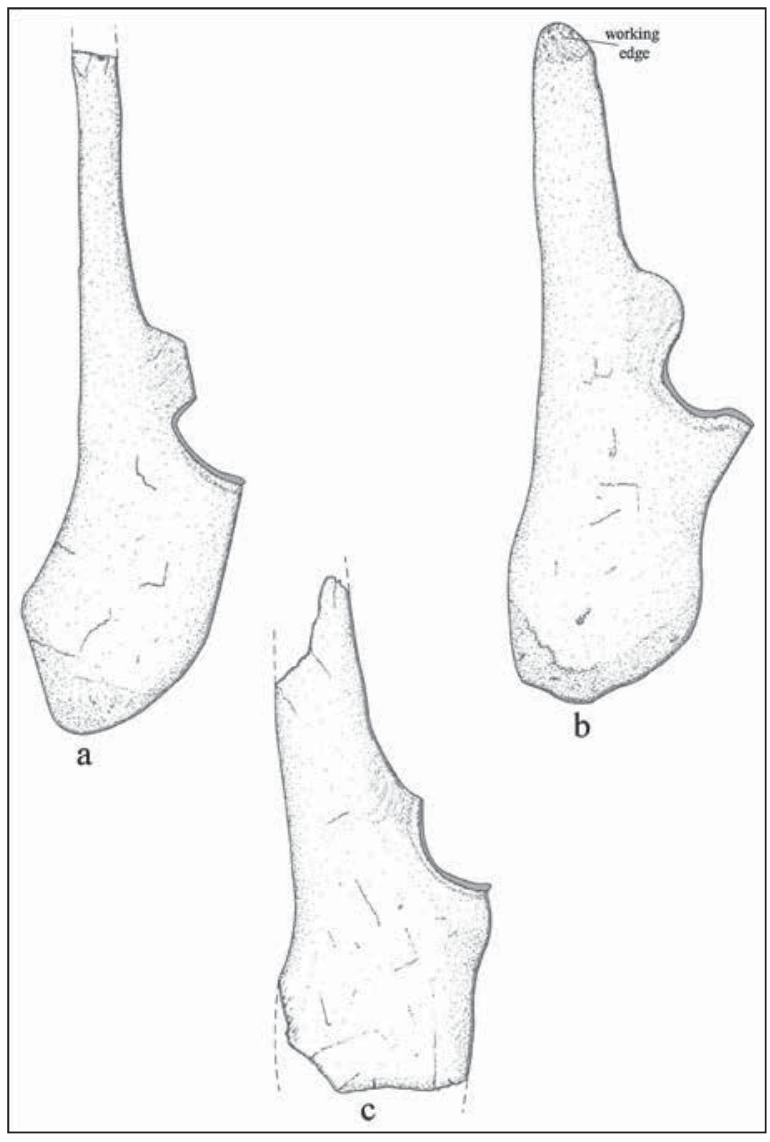

Figure 4. Deer bone ulna awls from the Walter Bell site.

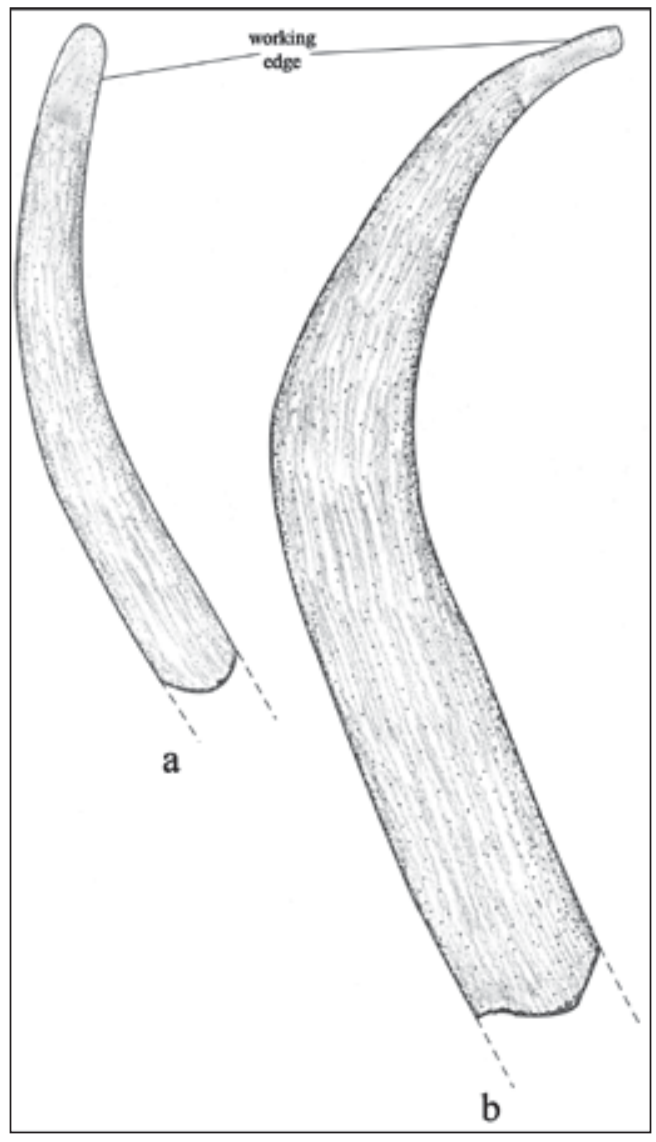

Figure 5. Antler tine tools from the Walter Bell site. 
Four long bone shaft fragments were shaped into flaking tools with polished and worn tips (Figure 6). These fragments ranged from $54.0-85.3+\mathrm{mm}$ in length and $11.0-11.3 \mathrm{~mm}$ in width. A bird bone was polished and shaped into a needle that was $>65.0 \mathrm{~mm}$ in length and was $7.0 \mathrm{~mm}$ in width (Figure 7). This needle may well have been a tool used for tattooing (see Deter-Wolf 2013:51-52). There is also a burned and polished long bone shaft fragment in the bone tool assemblage from the site.
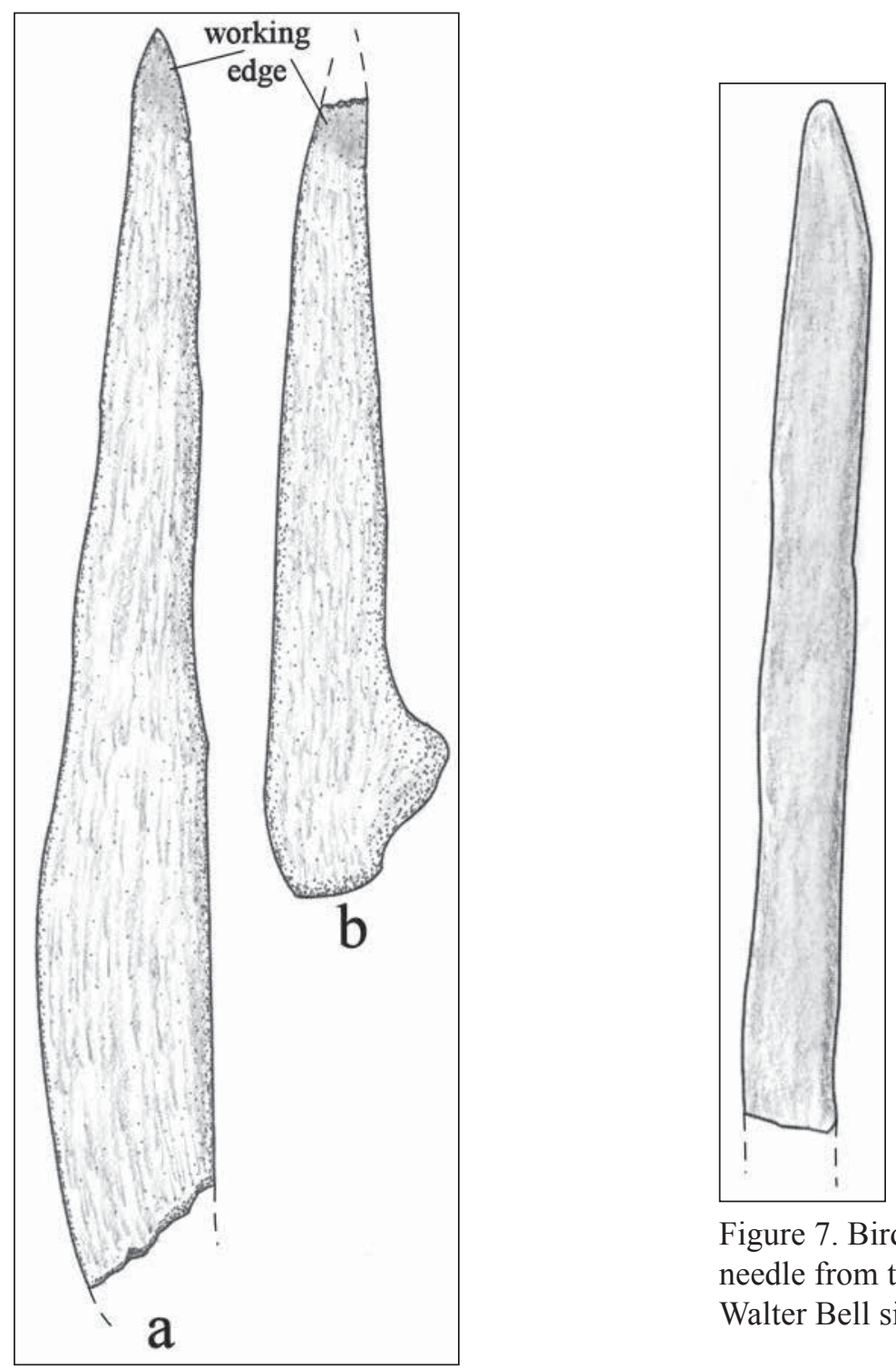

Figure 7. Bird bone needle from the Walter Bell site.

Figure 6. Long bone flaking tools from the Walter Bell site.

The last of the bone tools were two deer metapodial bones that had a shaped working edge opposite their articular ends that was rounded, beveled, and polished, perhaps from fleshing/scraping use as beamers (Figure 8) for deer hide processing (see Shafer 2006:13 and Figure 3). These tools ranged from 112.0-137.1+ $\mathrm{mm}$ in length and between $25.0-26.1 \mathrm{~mm}$ in width. 


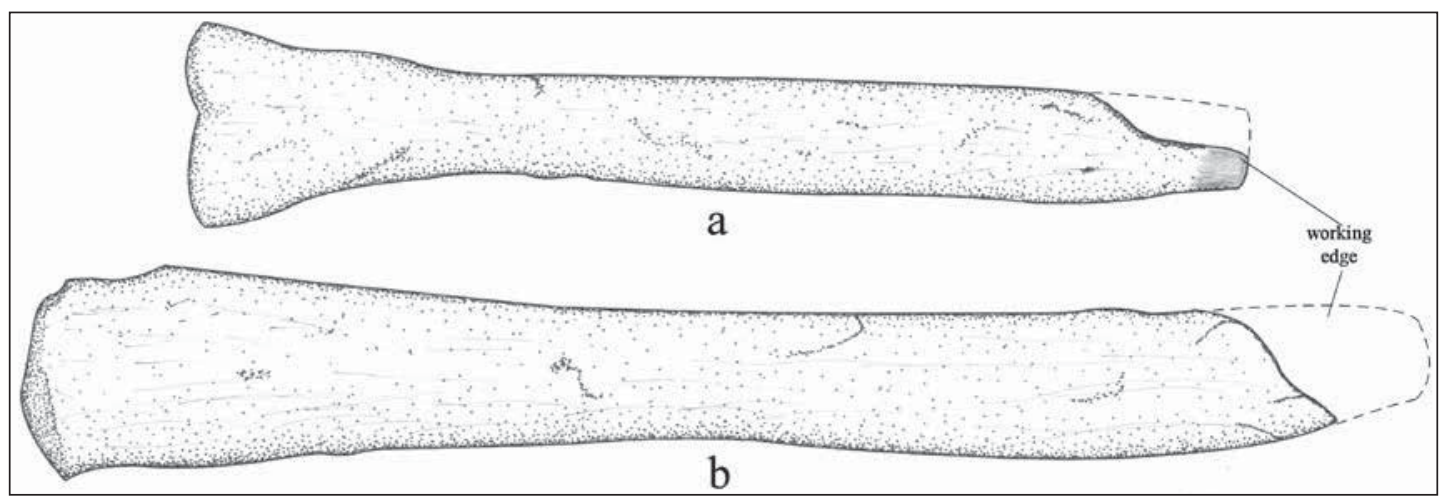

Figure 8. Metapodial bone tools from the Walter Bell site.

In addition to the bone tools, there is a turtle shell carapace rattle in the collections from the Walter Bell site. The carapace of this rattle has had its interior scraped, and there are two drilled suspension holes (3.1-4.1 $\mathrm{mm}$ in diameter) at one end (Figure 9). Overall, the turtle rattle is $107.3 \mathrm{~mm}$ in length, $71.0+\mathrm{mm}$ in width, and 2.5-6.4 $\mathrm{mm}$ in thickness.

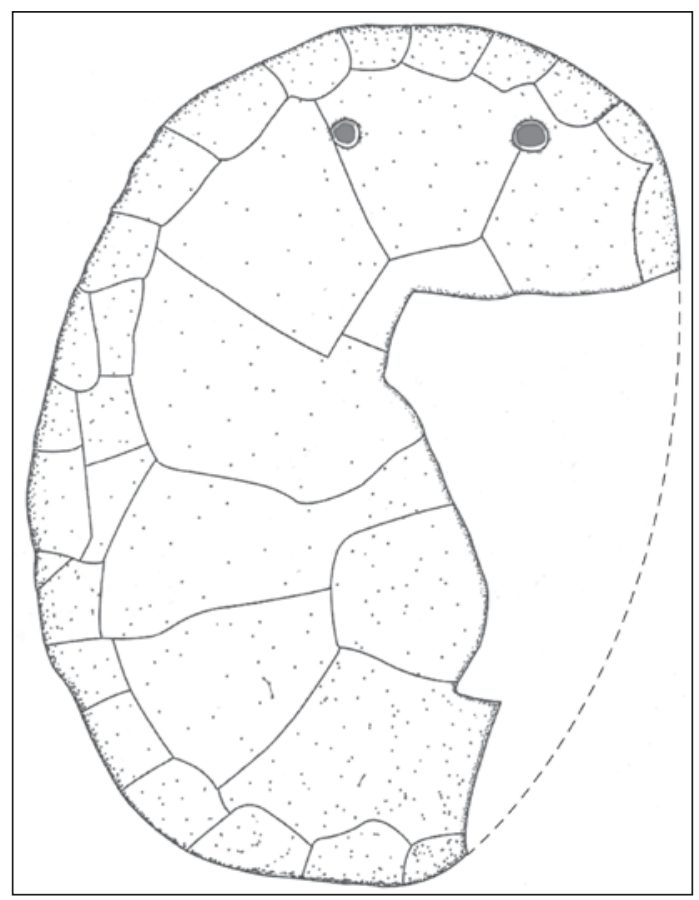

Figure 9. Turtle rattle from the Walter Bell site.

Bone tools of various forms and likely functions are preserved in the archaeological deposits in both early Angelina phase (ca. A.D. 1000-1400, but primarily dating after ca. A.D. 1200) and late Angelina phase (ca. A.D. 1400-1680) sites at Lake Sam Rayburn in the Angelina River basin (Table 1). Although certainly affected by sample sizes, the late Angelina phase sites have the greatest diversity in tool forms, but antler tine flakers and deer ulna awls are by far the most common tool forms in each assemblage. These two tool forms account for 88 percent of the tools in the early Angelina phase components and 69 percent of the late Angelina phase tools. 
Table 1. Bone tools from Lake Sam Rayburn sites.

\begin{tabular}{llll}
\hline Tool form & $\begin{array}{c}\text { early Angelina } \\
\text { phase }\end{array}$ & $\begin{array}{c}\text { late Angelina } \\
\text { phase* }\end{array}$ & $\mathrm{N}$ \\
\hline Flaker & 4 & 10 & 14 \\
Ulna awl & 3 & 14 & 17 \\
Long bone shafts with polished & - & 4 & 4 \\
$\quad$ and worn tips & & 2 & 3 \\
Antler beam handle & 1 & 2 & 2 \\
Metapodial beamer & - & 1 & 1 \\
Bird bone needle & - & 1 & 1 \\
Fish hook & - & 1 & \\
Long bone shaft fragment with & - & & 43 \\
polishing & & 35 & \\
\hline Totals & 8 & & \\
\hline
\end{tabular}

*a turtle shell rattle also present

Other important bone tool forms include deer bone shafts with polished and worn tips as well as polishing on the shaft body; these may be fragments of flakers, and they are present only in the late Angelina phase components (see Table 1). Antler beam handles with socketed ends are present in both early and late Angelina phase components, while a bird bone needle and a bone fish hook (see Table 1) occur only in the late Angelina phase component at the Walter Bell site.

\section{ACKNOWLEDGMENTS}

Lance Trask prepared the figures in this article. We also thank the Texas Archeological Research Laboratory at The University of Texas for access to the collections from the Lake Sam Rayburn sites, and thank Dr. Edward B. Jelks for encouraging our study of the collections.

\section{REFERENCES CITED}

Deter-Wolf, A.

2013 Needle in a Haystack: Examining the Archaeological Evidence for Prehistoric Tattooing. In Drawing with Great Needles: Ancient Tattoo Traditions of North America, edited by A. Deter-Wolf and C. DiazGranados, pp. 43-72. University of Texas Press, Austin.

Girard, J. S., N. Heller, J. P. Dering, S. L. Scott, H. E. Jackson, and G. L. Stringer

2011 Investigations at the Conly Site, a Middle Archaic Period Settlement in Northwest Louisiana. Louisiana Archaeology 32:4-76.

Jelks, E. B.

1965 The Archeology of McGee Bend Reservoir, Texas. Ph.D. dissertation, Department of Anthropology, The University of Texas at Austin.

Shafer, H. J.

2006 People of the Prairie: A Possible Connection to the Davis Site Caddo. Texas Department of Transportation, Environmental Affairs Division, Archeological Studies Program and Prewitt \& Associates, Inc., Austin. 